\title{
O REGISTRO DO BATISMO EM OPOSICCÃO AO DA CONVERSÃO: $O$ DISCURSO INACIANO NAS MISSÓES DO PARAGUAI NA PRIMEIRA METADE DO SÉCULO XVII
}

\author{
GUILHERME GALHEGOS FELIPPE ${ }^{1}$
}

PUCRS

\begin{abstract}
RESUMO: Frente aos objetivos postos pela empresa missionária e às necessidades referentes ao trabalho evangélico - dentre eles, o registro em correspondências do cotidiano reducional -, os jesuitas agregaram ao batismo uma grande importância não apenas como ritual de passagem para o cristianismo, mas também como instrumento discursivo para confirmar a conversão dos nativos e, assim, comprovar aos superiores o bom andamento das reduções. Porém, analisando-se o discurso inaciano, percebe-se uma grande incidência de relatos que sublinham a realização do batismo, sem haver a mesma proporção de relatos que comprovem a conversão destes índios recém-batizados. Há, portanto, uma desproporção no registro jesuítico na relação entre indígenas batizados e convertidos.
\end{abstract}

PALAVRAS-CHAVE: Reduções platinas; Discurso jesuítico; Batismo; Século XVII.

ABSTRACT: In light of the objectives imposed by the missionary enterprise and the needs of the evangelical labor - amongst which, the registry by correspondence of the day-to-day in the reductions -, the Jesuits have placed in the baptism a great importance, not only as a rite of passage on the conversion to Christianity, but also as an instrument of discourse to confirm the conversion of the natives and, thus, to prove to their superiors the adequate progress of the reductions. However, by analyzing the Ignatian discourse, a great incidence of stories that highlight the incidence of the baptism can be perceived, without there being the same proportion of stories proving these recently baptized Indians. There is, therefore, a disproportion in the Jesuitical registry of the proportion between baptized Indians and converts.

KEYWORDS: Platinian reductions; Jesuitic discourse; Baptism; XVII Century.

Quando chegaram à região platina, no final do século XVI, os jesuítas iniciaram a catequese dos índios por meio das chamadas missões itinerantes, onde faziam investidas a um vasto território, alcançando diversos povoados. Porém, permaneciam pouco tempo em cada aldeia, além de contarem com recursos escassos que impossibilitavam uma satisfatória difusão do evangelho. Os recém-

\footnotetext{
${ }^{1}$ Mestre em História - PPGH/PUCRS.
}

Espaço Ameríndio, Porto Alegre, v. 1, n. 1, p. 10-41, jul./dez. 2007. 
GUILHERME GALHEGOS FELIPPE - O registro do batismo em oposição...

batizados não permaneciam nesta condição por muito tempo, seja por falta de instruções adequadas, seja pela não permanência de sacerdotes que os motivassem à conversão. Com isso, os jesuítas tiveram de readaptar seu trabalho evangélico, inaugurando na região as missões por redução (MELIÀ, 1991 b), onde criaram uma rotina cristã voltada aos ensinamentos, realização de missas, sermões e catequese, assegurando, aos nativos, locais exclusivos à administração e difusão do evangelho.

Com isso, tratar da conversão dos índios fazia parte não apenas do dia-a-dia reducional, mas também dos registros referentes às correspondências que eram enviadas aos superiores e aos colegas da Companhia de Jesus. Descrever suas experiências e suas dificuldades, alertar os demais padres a certos perigos, relatar novos métodos de intervenção pastoral e informar qualquer tipo de situação ocorrida em uma missão eram, a grosso modo, os tópicos necessários presentes em uma carta jesuítica ${ }^{2}$. Dados valiosos que, através de análises, podem fornecer algumas interpretações - sempre superficiais - acerca do contato vivenciado entre jesuítas e índios no meio reducional ${ }^{3}$.

O presente artigo tem como objetivo explorar a potencialidade informativa dos registros presentes na correspondência inaciana, partindo do discurso sobre o batismo cristão realizado aos indígenas reduzidos. Para isso, será analisada a correspondência referente aos primeiros 40 anos de empresa reducional (1610-1650), na medida em que são décadas de instalação e estabelecimento das reduções, resultando cartas de "fundação" que se caracterizam por narrar de forma direta e imediata os diversos acontecimentos dos primeiros contatos permanentes entre jesuítas e índios (MELIÀ, 1988, p. 94). Além disso, verifica-se neste período uma grande quantidade de relatos referentes

\footnotetext{
${ }^{2}$ Sobre o conteúdo informativo da correspondência inaciana, cf. Londoño (2002). O autor salienta a importância que têm as informações relativas ao cotidiano reducional, de caráter subjetivo de cada autor incentivadas por Inácio de Loyola (LONDOÑO, 2002, p. 23) - e que não se centram apenas no trabalho apologético jesuítico. Segundo Federico Palomo, este recurso fazia com que a correspondência se tornasse um "instrumento para "conversar", tendo em vista que, espalhados pelo mundo, os jesuítas podiam usar as cartas como forma de "'encontrarse' y hacer presentes en la imaginación” (PALOMO, 2005, p. 58).

${ }^{3}$ Tem-se claro que qualquer análise sobre esta documentação deve ser realizada de modo prudente, visto serem registros baseados na "projeção de uma categoria ocidental, utilizada na época do contato para ler, entender, e finalmente construir o 'outro' indígena" (POMPA, 2001, p. 179). Além disso, Guillermo Wilde alerta que "los jesuitas se cuidaran de eliminar en sus escritos toda referencia a conflictos internos, ya que podían incitar las críticas de los enemigos de la orden" (WILDE, 2003, p. 207). Por isso, o escrito jesuítico deve ser considerado de acordo com sua função na estratégia evangelizadora, fazendo parte de "uma peça do dossiê das missões" (LABORIE, 2005, p. 13).
}

Espaço Ameríndio, Porto Alegre, v. 1, n. 1, p. 10-41, jul./dez. 2007. 
GUILHERME GALHEGOS FELIPPE - O registro do batismo em oposição...

ao batismo sacramental, que pode ser justificado pela necessidade político-religiosa que tinham os padres em informar os seus colegas o bom andamento da empresa evangélica. Isto porque a empresa reducional só poderia manter-se em atividade com o consentimento da Igreja que, por sua vez, só a aprovaria mediante resultados satisfatórios, provenientes das boas notícias trazidas pela correspondência.

O batismo, portanto, adquire papel fundamental nos relatos inacianos, fazendo parte de uma grande quantidade de suas descrições. Porém, esta expressiva incidência faz notar uma irregularidade em sua forma: a grande relevância quantitativa na correspondência religiosa é inversamente proporcional à sua interiorização na vida indígena; isto quer dizer que, apesar do sacramento ser muito citado pelos inacianos em seus relatos, poucas vezes evidencia-se registros que comprovam a conversão do recém-batizado.

Para tentar compreender qual motivo desta desproporção, serão analisados primeiramente casos que ressaltam a importância do sacramento na vida reducional, partindo-se dos relatos modelares que apresentam situações aparentemente edificantes, como batismos que curam ou a realização de batismos simultâneos, mas que acabam, em sua maioria, não resultando em conversões reais. Logo após, serão analisadas quatro situações pertencentes ao discurso batismal que poderão ajudar a entender a falta de registros que comprovem a eficácia do sacramento.

\section{O batismo como discurso edificante}

Atenta-se para o fato de que o batismo abriga três momentos importantes: os ensinamentos precedentes, o ato sacramental e a conversão à nova vida cristã. Este era o caminho correto que deveria ser seguido pelos índios que se instalaram nas reduções e envolveram-se no trabalho missionário. A conversão necessita dos ensinamentos prévios, tanto quanto necessita da dedicação do novo fiel, para toda a vida. Porém, analisando os registros batismais, observa-se que, raras vezes, esses três momentos aparecem juntos. Em uma carta de 1633, escrita pelo padre Diogo Ferrer, pode-se constatar um caso destes: 
GUILHERME GALHEGOS FELIPPE - O registro do batismo em oposição...

E teve um cacique chamado Guaibipo que, em todo o tempo que o padre esteve entre eles, nunca deixou passar um dia sem trazer algo a seu padre. Este mesmo bom Guaibipo, com sua mulher, nunca faltou à doutrina, manhã e tarde, e por mais que fosse muitas vezes sozinho com sua mulher à casa do padre, pedindo-lhe que lhes ensinasse dizendo que não se cansava de ouvir a palavra de Deus. Assim logo soube a doutrina e o padre batizou-o e casou-o com solenidade o primeiro de todos (MCA, 1952, p. 35-6) ${ }^{4}$.

Diogo Ferrer enfatiza todo o aprendizado e dedicação que o cacique teve antes de receber o batismo. Essa sua postura é aprovada pelo jesuíta que não duvida de sua inclinação à conversão, criando um relato edificante com um final satisfatório: o cacique é batizado e casase cristianamente. O matrimônio foi relatado de forma a confirmar o bom destino do novo cristão, tornando o sacramento eficaz. Passando pelas três situações graduais - ensinamentos, sacramento e permanência -, o indígena está envolvido em um caso modelar, um exemplo do bom trabalho missionário. Assim aparenta ser um relato de 1627, em que o padre Pedro Romero enaltece o batismo de 25 adultos, "todos bem preparados e desejosos", pedindo, ao final, que "faça o Senhor a todos bons e fervorosos cristãos" (MCA-CPH, cx. 28, doc. 22). Seu desfecho não indica objetivamente que todos tiveram um destino cristão favorável. É esse justamente o problema encontrado na correspondência jesuítica: tais casos chamados aqui de modelares, ou seja, que apresentam o registro completo de todas as situações que envolvem o batismo - e não só o ato sacramental - são escassos, existindo mais relatos voltados somente a registrar o batismo em si. Em outro caso de 1627 ocorre a mesma situação:

Foram catequizando e batizando também os jovens, acudindo todos com grande disposição e afinco do santo batismo, de maneira que em poucos meses batizaram-se mais de quinhentas crianças, e ao pé de duzentos jovens, todos muito bem instruídos, nos quais o padre Ruyer trabalhou sem cessar gastando quase todo o dia com eles (MCA, 1970, p. 63).

\footnotetext{
${ }^{4}$ Optou-se por citar os trechos referentes às cartas jesuíticas em português, de maneira a facilitar a leitura e torná-la mais fluente, tendo em vista que os originais estão em espanhol arcaico, muitas vezes repletos de abreviações. Mantêm-se as referências para eventuais consultas.
} 
GUILHERME GALHEGOS FELIPPE - O registro do batismo em oposição...

Em seu relato, o padre Cláudio Ruyer tem a intenção de registrar os batismos realizados em crianças e jovens, dando importância ao número de índios sacramentados. O jesuíta escreve que todos os batizados foram bem instruídos, mas não informa se tiveram uma vida cristã satisfatória após a conversão. Em se tratando do batismo de crianças e jovens, obviamente torna-se difícil qualificar o destino dos novos cristãos, porém ressalta-se aqui a importância dada pelo autor do relato às quantidades de batismos realizados, glorificando tais ganhos à cristandade. Ao contrário, observa-se um registro de 1614 onde o jesuíta dá importância a outra informação:

A mãe do cacique principal até esse tempo havia sido infiel. Pediu a seu filho que a fizesse batizar com os padres, e a deixasse viver junto a eles para que a enterrassem na igreja quando morresse. Realizou-se o batismo com grande admiração dos índios, e [a índia] vive próxima da habitação dos padres como se fosse antiga cristã (MCA-CPH, cx. 25, doc. 14).

Não mencionando qualquer ensinamento ou preparo dado à índia, o autor do relato atenta para o fato de ela ter querido, por vontade própria, a conversão, mas principalmente por ter permanecido uma boa cristã. O sacramento foi bem realizado e eficaz, apesar de não ter sido mencionado o preparo para isso: aqui, a vontade da mãe do cacique foi o suficiente. Mesmo assim, casos onde é registrado o comportamento tomado pelo recém-batizado são raros. A grande maioria dos registros envolvendo o batismo costuma enfocar o ato sacramental em si, normalmente não ressaltando preparos e, raríssimas vezes, dando conta do que ocorreu com o novo fiel. A falta destas informações principalmente a que diz respeito à situação pós-batismal do neófito torna o registro inaciano debilitado e duvidoso, visto não se ter qualquer confirmação da interiorização do sacramento por parte dos nativos. Sem dúvida, a realização do batismo ocorre - ao contrário da conversão e da permanência indígena na cristandade, que parecem ter sido menos freqüentes na realidade reducional.

Salienta-se também outra função atribuída ao batismo no registro inaciano: o poder de cura. Como coloca Eliane Fleck, a manipulação da 
medicina nas reduções era cargo dos jesuítas, que quase nunca tinham qualquer preparo voltado para a área médica. Associado a isto, a falta de medicamentos e instrumentos específicos forçava os padres a usar uma "terapêutica mágica, baseada na administração dos sacramentos, do licor de São Nicolau, das imagens de santos, de relíquias e da água benta", revelando a intenção dos jesuítas de controlar o "processo de cura, potencializando a conversão dos indígenas com a promessa da vida eterna" (FLECK, 2006, p. 160-161).

Normalmente, são casos em que os jesuítas aplicam o batismo a índios doentes ou gravemente feridos que melhoram seu estado físico em função dos poderes atribuídos ao sacramento. Como descreve Montoya a respeito de uma índia encontrada com ferimentos de flechada na barriga que, segundo o autor, "muito breve sanou" após receber o batismo (MCA, 1951, p. 278). O registro dá um caráter mágico à situação, revestido de mistério e eficácia divina, depositando no jesuíta a imagem de guardião e controlador desses poderes, já que é ele quem administra o sacramento e, por isso, possibilita a cura. Porém, mesmo sanando a ferida, nada se registra sobre uma possível conversão da índia: trata-se do corpo, e não da alma. A cura é o fator importante no registro, desviando-se toda a atenção a ela, como em um caso bemsucedido ocorrido a um menino quase morto que, após ser batizado, curou e ficou "muito lindo e belo", afirmando o autor do relato que "é maravilhoso ver como sanam todos que se batizam" (DHA, 1927, p. 89), e o mesmo ocorrendo a um cacique principal doente que "disse publicamente que o batismo curou-o" (MCA-CPH, cx. 28, doc. 18). Poder-se-ia continuar a listar diversos outros casos que enaltecem a realização batismal e associam-lhe um poder mágico de cura, mas o que se quer sublinhar aqui é justamente o desvio de função que o sacramento adquire nestes registros. Apesar de serem casos edificantes que enaltecem a boa realização do batismo, nenhum deles trata do comportamento religioso do índio recém-batizado. Desta forma, a eficácia destes batismos limita-se apenas à cura física do índio, adquirindo, dentro do discurso inaciano, uma função distinta da proposta inicial.

A prioridade nestes registros é confirmar a realização do ato batismal, dando a entender que esta informação já bastaria para 
GUILHERME GALHEGOS FELIPPE - O registro do batismo em oposição...

confirmar, perante os superiores e demais colegas da Companhia de Jesus, o bom andamento da empresa reducional. Deve-se a isto a existência de uma grande quantidade de relatos voltados apenas em registrar os batismos, principalmente aqueles que privilegiam quantidades: "Andou entre eles em missão por muito tempo o padre Ortega e batizou mais de vinte e dois mil índios" (DHA, 1927, p. 17).

Não cabe aqui questionar a quantidade numérica citada, mas sim analisar o tom impresso no relato. Sendo o número um exagero ou não, Diego de Torres glorifica seu companheiro pela façanha de batizar tantos índios, não existindo a preocupação em registrar o destino destes novos cristãos. Assegurar uma grande quantidade de sacramentos realizados parece ter sido a maior preocupação dos jesuítas que vão acabar dando mais importância para o ato batismal do que para sua eficácia: "O número de batizados que se encontram atualmente vivos, entre adultos e crianças, é de mil cento e cinco" (MCA, 1970, p. 70-71). Registrar esta grande quantidade de batismos é a forma como os jesuítas provam o bom andamento do trabalho realizado junto aos índios que, de acordo com estes números, vão aderindo cada vez mais à religião cristã. Em registro de 1628, o padre Nicolau Duran expõe números mais detalhados, enaltecendo os ganhos e finaliza o relato de forma otimista:

Conta-se nela [Redução de Nossa Senhora da Natividade do Acarai] 400 famílias e 1050 batizados: 500 adultos, sendo o restante, crianças e todos já próximos do batismo. No dia de hoje estarão já todos batizados (MCA, 1951, p. 206).

Sua preocupação é justamente mostrar a boa quantidade de índios que têm sido batizados e assegurar que todos que ali vivem passarão pelo sacramento. Este tipo de relato acaba tendo uma função paliativa, pois seu objetivo limita-se a informar como está indo a difusão do cristianismo, apresentando apenas uma parte da realidade: fala-se em batismos, não em conversões. A eficácia do sacramento é demonstrada pela freqüência de rituais realizados, e não pela importância dada aos índios e permanência destes na nova vida cristã. A falta de registros pós-batismo aponta para a dificuldade que os jesuítas tinham em converter índios, obrigando-os a focar a atenção dos relatos no ato 
GUILHERME GALHEGOS FELIPPE - O registro do batismo em oposição...

sacramental. Desta forma, batizar não parece ter sido o maior problema para os jesuítas, mas sim convencer os indígenas a permanecerem atuando conforme os preceitos cristãos na rotina reducional. Pos isso, é comum encontrar relatos denunciando atitudes que demonstram, aos olhos jesuíticos, contradições no comportamento nativo, como "alguns [índios] cristãos que, nos anos passados, voltaram-se aos infiéis e tomam seus antigos costumes" (MCA-CPH, CX. 28, doc 12), ou quando o padre Horacio Vecchi reclama da má vida que "quinhentas almas" levavam na ilha de Santa Maria (na província do Chile), pois, "ainda que alguns deles eram cristãos, não viviam como tais, porque não havia quem os ensinasse a lei de Deus, e assim todos como infiéis tinham muitas mulheres e outras mil superstições" (DHA, 1927, p. 59). Ao que tudo indica, o batismo não assegurava a conversão indígena, como bem percebeu o padre Diogo de Boroa: "o grande inconveniente que é batizar estes índios e deixá-los a suas aventuras ou desventuras, nos mesmos costumes de sua infidelidade" (MCA, 1952, p. 15).

Analisando os relatos jesuíticos que envolvem o batismo, encontram-se quatro situações que estão diretamente ligadas a esta atitude irascível indígena. São casos onde se pode observar a dificuldade que os padres tinham em converter os índios, ou seja, registros que acabam enfocando - talvez despropositadamente - ou a falta da conversão, ou uma conversão questionável, mesmo que precedida pelo ato batismal. São quatro situações que serão divididas em dois tipos. $O$ primeiro faz referência a duas respostas ativas dos índios frente ao sacramento: o ritual de desbatismo e o medo do batismo. São atitudes indígenas observadas e descritas pelos jesuítas de forma pejorativa e tendenciosa, de forma a registrar a incompatibilidade que os nativos têm para com o sacramento cristão. No segundo tipo estão as reações jesuíticas movidas pela dificuldade em converter os índios: o batismo urgentista e o batismo procrastinado. Ao contrário das situações anteriores, estas atitudes são manobras discursivas criadas pelos padres de forma a reverter o problema do batismo que não assegura a conversão indígena.

Estas quatro situações, que normalmente passam despercebidas à leitura dos registros sobre o batismo, apontam para um mesmo foco: a tomada de ação de ambos os lados para o problema posto - que aos 
GUILHERME GALHEGOS FELIPPE - O registro do batismo em oposição...

olhos inacianos é a realização de batismos que não garantem a conversão e aos olhos indígenas, a imposição de novos rituais e dogmas incompatíveis com seu modo de ser. A análise destas situações servirá para compreender como jesuítas e índios portavam-se frente a frente na realidade reducional.

\section{Desbatismo}

O ritual de desbatismo é a primeira situação relacionada à irredutibilidade indígena que será analisada, devido à sua pouca incidência na documentação consultada. Porém seu escasso registro tem, como se verá, um motivo que é bastante importante para este trabalho. Cabe lembrar também que não é intenção aqui analisar rituais e costumes indígenas do século XVII, e sim analisar o discurso jesuítico realizado em conseqüência do contato, e daí tentar compreender a forma como ambos os personagens colocavam-se frente a frente. Desta forma, tem-se claro que todo registro jesuítico é promovido de acordo com sua visão de mundo e cultura, cabendo às suas funções, aos seus objetivos e deveres, relatar o que observa.

O ritual de desbatismo só é conhecido por nós devido aos relatos jesuíticos, por isso sua existência é repleta de questionamentos. Não se sabe se era um ritual de praxe indígena, realizado conforme as necessidades nativas, assim como outros rituais autóctones casamento, nomeação, caça, exéquias - que foi mal interpretado pelos padres, assim como não se sabe se sua criação se deu realmente devido ao contato jesuítico-indígena como uma resposta nativa ao batismo cristão - como descreviam os padres -, ou se era uma ritual nativo que tomou novos significados e atualizações em função do contato. De qualquer forma, o importante aqui é justamente a existência do relato do ritual que, mesmo sendo quantitativamente baixo, importa pelo seu caráter qualitativo: são registros escassos, porém apresentam informações peculiares sobre a situação do trabalho jesuítico. Isto porque são relatos inesperados, que fogem do padrão discursivo dos padres - ao contrário dos registros que atentam para o pós-batismo, 
GUILHERME GALHEGOS FELIPPE - O registro do batismo em oposição...

que deveriam ser freqüentes pela sua importância no trabalho reducional.

De toda a documentação consultada ${ }^{5}$, foram encontrados apenas dois relatos que citam objetivamente o ritual de desbatismo. Um está descrito em uma carta que dá conta dos fatos ocorridos logo após a morte do padre Cristóvão de Mendoza, em 1635, sem assinatura do seu autor. O outro relato foi escrito pelo padre Montoya em seu livro impresso em 1639. Ambos descrevem aparentemente o mesmo ritual, porém com algumas diferenças no que tange aos personagens envolvidos. Para facilitar a análise destes relatos, ambos serão citados respectivamente:

Estava um deles [xamãs] fazendo seu razoamento e predicando atualmente, e o outro batizando uma índia contrafazendo e fazendo burla do que os padres faziam: o modo de batizar era lavar-lhe todo o corpo, dos pés à cabeça, dizendo "tayti ndecaray hague", que quer dizer "lavo-te para tirar o batismo que te deram" (MCA, 1970, p. 257-258).

Neçú, de sua parte e para mostrar-se sacerdote, conquanto falso, revestiu-se dos paramentos litúrgicos do padre e com eles se apresentou ao povo. E fez trazer em sua presença as crianças, nas quais tratou de apagar com cerimônias bárbaras 0 caráter indelével, que elas pelo batismo tinham impresso em suas almas. Raspou-lhes as pequenas línguas, com que haviam saboreado o sal do espírito sapiencial. O mesmo fez-lhes no peito e nas costas para borrar os santos óleos, que as tinham prevenido para a luta espiritual (RUIZ DE MONTOYA, 1985 [1639], p. 201202).

Observando-se os relatos, nota-se, primeiramente, que ambos os rituais citados são promovidos por índios feiticeiros - no primeiro, os xamãs que ordenaram a morte do padre Cristóvão de Mendoza e, no segundo, o feiticeiro Neçú. Esta situação é esperada, na medida em que se tem conhecimento da rivalidade entre jesuítas e feiticeiros. Em sendo os xamãs os detentores dos poderes mágicos e sobrenaturais nas comunidades ameríndias, os jesuítas viam-nos como um empecilho à

\footnotetext{
${ }^{5}$ Foram analisados cerca de 150 registros que envolvessem o batismo sacramental, distribuídos em cartas do período entre 1609 e 1650 .
} 
GUILHERME GALHEGOS FELIPPE - O registro do batismo em oposição...

difusão do cristianismo em meio aos índios. Tal relevância atribuída aos feiticeiros justifica um grande número de casos relatados envolvendo práticas xamânicas, normalmente com $\mathrm{o}$ intuito de denunciar $\mathrm{e}$ desmistificá-las, a fim de colocar os indígenas contra as feitiçarias, ritos e cerimônias supersticiosas até fazer-lhes ter horror dos xamãs (RÍPODAS ARDANAZ, 1984, p. 202-203). "Os sacerdotes imediatamente identificaram os 'chamanes y sus embustes' como o inimigo a combater, porque em verdade representavam uma variante regional do mesmo demônio que atuava na Europa das heresias" (SANTOS, 1998, p. 338).

Quando os jesuítas se apresentam como novos portadores da verdade e buscam implantar uma nova concepção religiosa, os xamãs são os primeiros a sentir tal mudança. Com medo de caírem em descrédito, iniciam movimentos contrários à missão cristã, tendo que reafirmar seu poder mágico-religioso.

Para os feiticeiros, a missão jesuítica parecia ser uma afronta à sua crença, costumes e cultura. Por isso, o ritual de desbatismo parece ser uma reação xamânica às cerimônias cristãs. Porém, pode-se afirmar apenas que a sua descrição, realizada pelos jesuítas, tem um caráter tendencioso. Percebe-se isto pela interpretação que os padres dão ao ritual, entendendo-o como um instrumento criado de forma a confrontar o batismo, e por este motivo seguiria o modelo cerimonial cristão. Ruiz de Montoya (1985 [1639], p. 201) afirma que Neçú usava os "paramentos litúrgicos" sacerdotais para se assemelhar aos jesuítas, assim como, em outro relato, um grupo de feiticeiros, cuja intenção é matar os padres, é descrito também como plágio:

E, para conseguir este seu diabólico intento, fizeram uma artimanha infernal que foi arremedar e contrafazer todas as ações dos padres, em lugares como igrejas, onde se juntavam e tinham uns púlpitos e batistério. Ali, faziam seus razoamentos e batizavam ao seu modo, colocando nomes aos batizados (MCA, 1970 , p. 252-253).

De acordo com os registros, as atitudes xamânicas são resultados da investida jesuítica na região, só sendo possíveis em razão de sua existência. Por isso, tais cerimônias são relatadas com menosprezo pelos padres. Além disso, ambos os relatos que descrevem o ritual de 
GUILHERME GALHEGOS FELIPPE - O registro do batismo em oposição...

desbatismo parecem ressaltar a não-compreensão dos sacramentos cristãos pelos feiticeiros. Ambos são categóricos ao afirmar que os xamãs lavavam os índios "dos pés à cabeça" e raspavam-lhes "as pequenas línguas", fazendo o mesmo "no peito e nas costas", de modo a "apagar" do corpo "o caráter indelével" que foi "impresso em suas almas" (MCA, 1970, p. 258; RUIZ DE MONTOYA, 1985 [1639], p. 202). A limpeza livrava-os do mal que foi depositado: segundo os inacianos, para os índios a cura do corpo parece ser mais importante do que a da alma - o que, como foi visto anteriormente, não se opõe completamente ao que registravam os jesuítas sobre suas atuações para com feridos e moribundos.

Quando descreviam o ritual de desbatismo, os padres reafirmavam a sua rivalidade com os feiticeiros, apresentando, do seu modo, as cerimônias e atitudes xamânicas. Desta forma, concretizavam o seu discurso sobre os malefícios que a presença dos feiticeiros traziam aos indígenas, alertando os demais jesuítas, por intermédio das correspondências, e pregando aos índios o afastamento de seus antigos líderes religiosos. Por outro lado, estes mesmos relatos sobre o ritual de desbatismo acabam deixando escapar informações prejudiciais à empresa jesuítica.

Analisando os dois relatos, encontram-se pelo menos dois personagens em comum essenciais para a realização do ritual: o xamã, cuja presença já era esperada nesta situação, e o índio batizado, cuja presença é justamente o ponto crítico do relato. Estes índios que se submetem ao desbatismo estão, por meio do ritual nativo, apagando o ritual cristão. Desta forma, os jesuítas, com intenção de menosprezar os feiticeiros, acabam comprovando a irredutibilidade indígena e a ineficácia do sacramento batismal. Com isso, verifica-se que não eram apenas os xamãs os personagens atuantes em relação às investidas inacianas, mas os próprios indígenas que se submetiam a elas. Apesar de parecer uma contradição, esta situação ilustra uma tomada de ação por parte dos nativos, que não deixavam de viver de acordo com seus antigos costumes ao mesmo tempo em que seguiam as normas reducionais - por exemplo, saboreando "o sal do espírito sapiencial", mas sem pegar gosto por ele. 
GUILHERME GALHEGOS FELIPPE - O registro do batismo em oposição...

\section{Medo do batismo}

O ritual de desbatismo é um problema na medida em que descreve o retorno indígena à antiga condição de infiel, tornando todos os preparos e a cerimônia batismal inúteis, além da perda de confiança na conversão indígena. Esta situação comprova a existência de reações contrárias aos preceitos jesuíticos, movidas pelos feiticeiros, realizadas após o batismo e, ao que tudo indica, longe dos olhos sacerdotais. Outra reação aparece de forma diferente: antes mesmo da aplicação do batismo. Em diversos relatos, os padres registram casos em que os índios colocam-se contrários ao sacramento no momento em que o jesuíta iria administrá-lo, voltando "as costas a Deus, fazendo-se surdos a seu chamado" (MCA, 1969, p. 87). É desta maneira que uma índia, mesmo doente, "rehusaba obstinadamente el bautismo" (DUVIOLS E SAGUIER, 1991, p. 68), mostrando-se irredutível. Sem apresentar o motivo que a levava a negá-lo, Roque González afirma que tentou, junto com o padre Romero, realizar o sacramento diversas vezes, visitando-a seguidamente sem obterem bons resultados. Somente depois de muito tempo e insistência, o batismo é realizado e seguido pela morte da índia. Mesmo que o sacramento tenha sido aplicado e o relato seja de teor edificante, não se pode ignorar o fato de a índia ter negado, num primeiro momento, o batismo, talvez com receio de que algo ruim pudesse acontecer - o que, por sinal, aconteceu.

Apesar das precauções e persistências, os padres enfrentam a dura realidade de ter o batismo negado pelos índios. O motivo desta não-aceitação parece ser o medo que os indígenas sentiam, acreditando que o batismo levava à morte. Por serem épocas de fortes pestes na região que assolavam violentamente a população indígena, muitos nativos adoeciam e morriam rapidamente, assim como as crianças que acabavam sendo as principais vítimas. Aos padres não restava mais do que localizar os moribundos e aplicar-lhes o batismo de forma a salvar suas almas ${ }^{6}$.

${ }^{6}$ É recorrente encontrar nos registros inacianos casos que exemplifiquem esta situação. Muitos dos indígenas que são atendidos pelos jesuítas nunca chegaram a viver junto aos padres, como se observa em um relato de Pedro Romero que, ao ficar sabendo de um índio muito doente no meio da mata, foi socorrer-lhe para aplicar o batismo, mesmo 
GUILHERME GALHEGOS FELIPPE - O registro do batismo em oposição...

Movidos por este medo, muitos pais escondiam seus filhos recém-nascidos, preferindo, segundo Pedro Romero, "que morressem sem batismo, do que nos dá-los e mostrar aos padres para que os batizassem" (MCA, 1969, p. 85). Frente a esta situação, alguns sacerdotes chegavam a extremos, "tirando-os com muita sagacidade de onde estavam escondidos" (MCA-CPH, cx. 28, doc. 15). O mesmo ocorria com doentes que eram escondidos ou não eram anunciados, privando-lhes do batismo "de maneira que os parentes do doente às vezes o impedem sem razão disso" (MCA-CPH, cx. 28, doc. 18). Em 1621, Diogo de Boroa presenciou a tentativa de um índio de não permitir a realização do batismo de sua esposa doente, "temendo que, se fosse batizada, logo morreria", e finaliza, concluindo, que esta era uma "persuasão do demônio" (MCA-CPH, cx. 28, doc. 17). Esta associação é compreensível na medida em que, segundo Delumeau (1989, p. 248), o medo do diabo, na Europa, alcança o seu auge entre os anos de 1575 e 1625. Sendo assim, o discurso jesuítico estava contaminado daquela realidade européia, e é possível supor que os padres trouxeram consigo todos os aparatos necessários - incluindo o discurso do medo - para lidar com o demônio na empresa missional. Por isso, cada vez mais este personagem estava presente nas correspondências jesuíticas, impossibilitando a aceitação eficaz dos índios ao cristianismo e cada vez mais ganhando corpo, rosto e até trejeitos, chegando a ser descrito como uma figura humana (DHA, 1927, p. 106), podendo até mesmo dançar (MCA, 1951, p. 274-275).

Nestes relatos, o demônio pode aparecer na forma humana ou de até mesmo de um tigre, que fala com os índios, e quase sempre os ameaça (cf., por exemplo, MCA, 1970, p. 253-254). São, na verdade, representações dos xamãs que estes próprios sustentam, quando afirmam para os seus seguidores que podem se transmutar em animais e comunicar-se com o além, ou quando promovem danças e cantos

sabendo que este nunca tinha vivido no meio reducional (MCA, 1969, p. 37-8). 
GUILHERME GALHEGOS FELIPPE - O registro do batismo em oposição...

rituais $^{7}$. Os jesuítas os incorporam no seu discurso sobre o demônio, transformando-os no diabo.

Daí que os feiticeiros foram os grandes culpados por esta associação entre batismo e medo da morte. Sendo os principais inimigos da empresa evangelizadora, difundiam, segundo os inacianos, a idéia de que as práticas jesuíticas eram as responsáveis pelos malefícios vivenciados na época.

Los registros de este fenómeno muestran que los profetas indígenas que enfrentaron los males traídos por los conquistadores y misioneros no eran simplemente anunciadores del mal y mucho menos que interpretaban este mal como una decisión divina. Para ellos, la desgracia era causada por los que "se dejaban amansar" por el bautismo cristiano, por el espacio reducido, por una nueva religión, por un nuevo tiempo, una nueva cultura (CHAMORRO, 2004, p. 99).

Movidos pelo conflito com os jesuítas, os xamãs relacionaram o batismo a uma magia negra que matava, ao contrário do que os padres queriam difundir, onde o batismo traria cura e salvação. Montoya queixa-se desta má associação:

Não há, porém, lugar, em que o Evangelho não ache contradição da parte dos magos, ministros do demônio, que atribuem a morte ao batismo e assim procuram afastar os índios deste Sacramento (RUIZ DE MONTOYA, 1985 [1639], p. 222).

O mais curioso é que o inaciano, algumas páginas antes, tratando sobre a mesma relação batismo-morte, assume: "Deu-se, aliás, coisa idêntica em outros velhos que, mesmo batizados com saúde, de repente morriam" (RUIZ DE MONTOYA, 1985 [1639], p. 216). O padre Roque González faz a mesma constatação acerca das crianças: "Fuera de estas personas ya adultas había muchas criaturas pequeñas y niños algo más grandes, los cuales, apenas bautizados, han sido recogidos por Dios al

\footnotetext{
${ }^{7}$ Conferir, por exemplo, o caso do xamã que "pretendia ser o Deus das enfermidades" (DHA, 1929, p. 590-591), e os feiticeiros que diziam ser os responsáveis pelas plantações e comida, mas que haviam lançado uma praga de ratos na lavoura de forma a persuadir os indígenas (MCA, 1970, p. 280). Para uma análise sobre a importância dos feiticeiros e suas práticas ligadas aos cantos, danças, palavras sonhadas e rituais de restrições e nomeações na religião guarani, cf. Melià (1991a). Sobre o carisma ambíguo dos xamãs, que promovia nos índios sentimentos de temor e veneração, além da análise dos movimentos de sublevação, cf. Rípodas Ardanaz (1987).
} 
GUILHERME GALHEGOS FELIPPE - O registro do batismo em oposição...

cielo" (DUVIOLS, 1991, p. 68). O medo indígena, iniciado pelos feiticeiros, parecia não ser tão absurdo à realidade vivida.

Em 1634, o padre Pedro Romero descreve um longo caso ocorrido a uma índia gravemente doente que recusava obstinamente o batismo, movida pelos conselhos de um feiticeiro, segundo o autor do relato. Após diversas visitas do padre e sob sua insistência, a índia, já quase inconsciente, aceita a realização do sacramento, morrendo logo após sua aplicação (MCA, 1969, p. 82). O relato revela todo o procedimento complicado que precedia o batismo. O padre, que até o momento não havia reivindicado sua conversão, procura a índia somente no momento de sua morte, e torna-se insistente quando negado. Apesar do desfecho do relato ser edificante, na medida em que o batismo é realizado, o registro apresenta a negação ao sacramento, influenciada por um feiticeiro. Somente com a insistência e paciência do jesuíta é que a índia consentiu realizar o batismo. Porém, o profetismo xamânico acaba ocorrendo: a recém-batizada morre. Não cabe ainda discutir as situações de batismo seguido de morte - que serão melhor observadas adiante -, mas é importante salientar a forma como o jesuíta autor do relato estrutura o seu discurso. Mesmo sendo uma contradição - medo do batismo que leva à morte resolvido com o batismo que levou à morte -, o relato torna-se um caso edificante, pois assim quis o autor do trecho. Seu foco era justamente apontar a má influência dos feiticeiros, mesmo que isso custasse a vida da índia. A morte foi boa, já que foi utilizada a recompensa do paraíso: a disputa entre o bem - o batismo que leva ao céu - e o mal - a influência dos xamãs. Isto porque, segundo os jesuítas, os feiticeiros enganam seus seguidores dizendo que o sacramento mata; enquanto os padres querem difundir que o batismo leva ao paraíso. Um jogo de palavras e sentidos que é manipulado de acordo com as escolhas e necessidades jesuíticas:

Tendo adoecido um muchacho, seus pais infiéis, por acreditarem nos embustes dos feiticeiros, esconderamno bem longe do povoado. O garoto instava, contudo, a que o levassem ao padre, para que o fizesse filho de Deus pelo batismo. Não o alcançou. Mas alguns índios, movidos pelos rogos do mocinho, levaram-no à casa do padre, visto que ele não queria ir à de seus pais. 
GUILHERME GALHEGOS FELIPPE - O registro do batismo em oposição...

Com isso se batizou e, no dia seguinte, rumou para o céu (RUIZ DE MONTOYA, 1985 [1639], p. 222).

Neste relato, Montoya deixa clara a discordância entre as partes envolvidas: os pais que tentam esconder o doente dos jesuítas aparentemente para que este não fosse batizado -, e o garoto que, segundo o autor, quer o sacramento. O registro enfoca justamente a atitude dos pais em relação à vontade do filho, de forma a ressaltar esta disparidade entre os dois: o menino que busca o batismo, e seus pais infiéis que, dando ouvidos aos feiticeiros, além de não confiarem nos jesuítas, têm medo do que possa vir a acontecer com seu filho. Foi preciso uma ação extrema para que o garoto fosse batizado e, como no caso anterior, merecedor da recompensa paradisíaca. Seus pais não acreditavam nos benefícios que o batismo sacramental trazia, já que nunca o haviam recebido. Para o inaciano, a condição infiel dos índios justifica as atitudes tomadas, pois é o esperado de indígenas que não se adequaram à vida reducional cristã, ao contrário do garoto que não tinha os vícios nativos de seus pais.

Esses relatos que descrevem, num primeiro momento, a negação por parte dos índios ao batismo sacramental, mostram concretamente casos de nativos irredutíveis que se voltam às suas tradições e aos seus líderes, contrariando a expectativa dos jesuítas. Mas são registros que acabam sendo edificantes, pois resultam no ato batismal. Ou seja, este tipo de relato é acionado de forma a glorificar o esforço dos padres: indígenas que não aceitam o batismo, mas que, devido ao bom trabalho jesuítico, acabam cedendo e consentindo com a aplicação do sacramento. Mesmo assim, revelam um lado complicado da empresa reducional, afinal de contas, os índios fogem do batismo e, mesmo que o aceitem, podem vir a retirá-lo pelo do ritual de desbatismo. Soma-se a isto a escassez de registros sobre o destino tomado pelos nativos batizados. Aqui se faz necessário observar um caso relatado pelo padre Montoya:

Assim, chegou a esta redução um índio estrangeiro, que, com más palavras e piores exemplos, inquietava o "pueblo". Ficando doente, aborreceu-se com as admoestações do padre, que queria persuadi-lo do batismo, e se fez levar do povoado a uma roça. 
GUILHERME GALHEGOS FELIPPE - O registro do batismo em oposição...

Seguiu-o o padre para lá, mas ele, fugindo mais, fezse carregar a um denso bosque, observando que os sinos e as arengas do padre o aturdiam. Mas a caridade deste encontro o trouxe de volta. Entretanto, nem com dádivas, nem com palavras amorosas, pôde ele abrandar aquele peito empedernido, pois o nosso índio virava o rosto para a parede, não querendo ouvilas. Infelizmente chegou a morrer com o seu pertinaz desejo de morrer infiel como os seus antepassados (RUIZ DE MONTOYA, 1985 [1639], p. 217-218).

Deparando-se com um índio que parecia não se adaptar ao meio reducional, Montoya não consegue, de forma alguma, sua concessão para o batismo. Neste relato, como nos anteriores, o indígena não quer receber o sacramento e por isso foge do padre até o fim, quando morre sem tê-lo recebido. A insistência e o esforço - bastante ressaltados no trecho - não foram suficientes, resultando numa morte ruim que, Montoya deixa claro, foi "desejo de morrer infiel como os seus antepassados" (1985 [1639], p. 218). Além disso, o padre deixa claro que só foi aplicar o batismo quando o índio ficou doente, ou seja, somente num momento de necessidade, não informando se tentou batizá-lo anteriormente. Pode-se observar a mesma situação nos casos anteriores, onde os jesuítas relatam tentativas de batismo perante índios moribundos ou crianças com risco de vida. Isto leva a crer que realmente o registrar do ato batismal é a prioridade, seja para ocupar as cartas com casos edificantes, seja para justificar uma morte boa, já que somente no trecho supracitado o indígena tem uma morte ruim, e nos anteriores todos morreram com mostras de salvação - mesmo que tenham primeiramente negado o batismo. Então, pode-se supor que, para o discurso jesuítico, o registro do ato do batismo é mais importante do que o da conversão em si? Ou, após o batismo, a vida que o novo cristão leva é menos importante do que seu batismo?

Para ajudar a responder a estas questões e compreender como funciona o discurso jesuítico frente à situação posta, faz-se necessário analisar o segundo tipo de situações derivadas dos registros batismais. Diferente das duas anteriores (ritual de desbatismo e medo do batismo), que partiam de ações indígenas observadas e registradas pelos jesuítas, as duas situações que serão agora analisadas referem-se a atitudes dos padres que são incorporadas em seu discurso. Deixam de ser relatos 
GUILHERME GALHEGOS FELIPPE - O registro do batismo em oposição...

contados por um sobre os costumes do outro, para serem registros das formas de se comportar perante o imprevisto da dificuldade na empresa reducional. Iniciar-se-á pelo batismo urgentista praticado no leito de morte, pois se refere diretamente à importância dada ao ato batismal e também pela sua grande incidência nas correspondências jesuíticas.

\section{Batismo urgentista}

Chamam-se aqui batismos urgentistas os casos que envolvem o sacramento realizado às pressas, algumas vezes solicitado pelo indígena, outras pela própria iniciativa dos padres, mas que, independente disto, é sempre aplicado a indivíduos próximos à morte. Esses são fatores importantes a serem ressaltados, na medida em que os relatos que envolvem este tipo de casos raramente explicitam qualquer inclinação à fé cristã do indígena batizado: aqui, não é o merecimento do indivíduo que regula a prioridade em aplicar o sacramento, mas sim o seu estado físico. Por isso, são batismos realizados a crianças, jovens, adultos e velhos, doentes ou feridos, cuja única esperança, segundo os jesuítas, é a salvação de suas almas. Como conseqüência disto, são casos em que o recém-batizado morre logo após a realização do sacramento, ficando a cargo deste fato o seu destino como novo cristão: a redenção perante a morte e sua alma seguindo para o paraíso. São, desta maneira, relatos edificantes, mesmo que não exista registro sobre a vocação indígena para o merecimento do batismo e nem a concretização de uma real conversão. Podem-se notar claramente estas características do discurso em um relato de 1609 em que o padre Aranda depara-se com um índio doente que, mesmo preso a uma armadilha pelo pé, trabalhava em suas terras. Percebendo a gravidade de seu ferimento e do estado avançado de sua doença, o jesuíta trata de retirá-lo do trabalho, de modo a tentar poupar sua saúde. Percebendo que não melhorava, restou-lhe a salvação de sua alma: o índio é batizado e, pela manhã, acaba morrendo (DHA, 1927, p. 28). O relato passa a ser edificante na medida em que o sacramento é realizado e o doente tem uma morte boa. 
GUILHERME GALHEGOS FELIPPE - O registro do batismo em oposição...

Geralmente, os registros que envolvem um batismo realizado às pressas, seguido pela morte do recém-batizado, têm este formato argumentativo, onde se apresenta o personagem envolvido, seu estado físico, a atuação do jesuíta, a realização do sacramento e a finalização satisfatória com a salvação de sua alma. A crítica que se faz a estes relatos é a falta de uma anunciação prévia da inclinação à fé cristã que estes personagens envolvidos possuíam. Neste caso supracitado, por exemplo, não se sabe a ligação que o índio tinha com os jesuítas ou à religião cristã. Seu batismo foi administrado em função de sua saúde precária, e não devido ao merecimento pela vocação.

Porém existem, dentro destas situações de batismos urgentistas, certos casos que o indígena envolvido é previamente qualificado pelo autor do relato. Nestes, é informada qualquer ligação que o personagem tenha com os jesuítas e/ou a cristandade, como se observa em um relato do padre Roque González:

Vivía aquí un joven oriundo de la provincia de Taraquira, el cual había abandonado a sus parientes no obstante los enérgicos, pero estériles, esfuerzos que hicieron para llevarlo otra vez a su tierra, porque deseaba él ser bautizado. No había logrado todavía éste su intento, cuando fue mordido por una víbora, cayendo en consecuencia de esto gravemente enfermo, y hallándose bastante lejos del pueblo. Me llamaron y luego me fui y le bauticé, y ya después de pocas horas, más dichoso que sus parientes abandonados por amor a Cristo Nuestro Señor, comenzó a vivir en el cielo con Dios a quien buscaba (DUVIOLS, 1991, p. 68).

A descrição que é feita do jovem ressalta a sua vontade em ser batizado, evidenciando o modelo de discurso edificante já desde o início do trecho. De modo a confirmar isto, o índio é batizado, de acordo com a sua vontade, e tem uma morte boa. Porém, o fato que o levou ao batismo foi a picada sofrida de uma cobra no mato. E é justamente aqui que se encontra a peculiaridade do relato: apesar da vontade que tinha em ser batizado - que, de acordo com autor, chegou a fazê-lo abandonar seus parentes -, o indígena só recebeu o batismo após o acidente. Sem justificar o porquê da não-realização do sacramento, mesmo a um índio desejoso, o autor deixa claro que foi o grave estado 
GUILHERME GALHEGOS FELIPPE - O registro do batismo em oposição...

do ferido o que motivou a aplicação do batismo, que acaba sendo realizado às pressas, como a única forma de salvá-lo.

O padre Diogo de Boroa, em 1621, escreve um caso sobre uma índia que já havia estado em uma redução, era catecúmena e, na época do ocorrido, vivia com os seus parentes em suas terras. Ao adoecer, tenta convencer seus familiares a levarem-na até os padres, que negam o seu pedido. Sozinha, então, desce o rio Paraná em uma canoa, chegando à redução de Encarnação, onde é catequizada novamente, batizada e, em seguida, morre (MCA-CPH, cx. 28, doc. 17).

Ressalta-se o esforço que a índia faz para ser batizada quando adoece. Tal vontade parece ser justificada pela sua condição de catecúmena, ou seja, já havia sido iniciada às crenças e dogmas cristãos de forma a prepará-la para o sacramento batismal. Provavelmente o seu batismo já era previsto, porém só foi realizado em razão da doença e também porque a índia foi até a redução procurar os padres. Apesar de o relato ser edificante por causa de sua estrutura - índia catequizada que adoece e supera todas as dificuldades para receber o batismo - e ter um final cujo desfecho é satisfatório à cristandade, questiona-se um fato registrado pelo inaciano: ao apresentar a índia, o autor escreve que ela já havia se reduzido junto aos padres, mas voltou às suas antigas terras para viver com seus parentes, todos descritos como "mal afectos" à religião dos jesuítas. $\mathrm{O}$ que acentua a discordância de fatos é que a doente era catequizada, supondo-se que para ganhar tal status teve que viver um bom tempo no meio reducional. Sua saída da redução deveria, seguindo a lógica jesuítica, ser repreendida e criar a desconfiança em relação à sua vontade em ser batizada. Nada garantiria que, após o batismo, a índia não fosse voltar a viver com os seus parentes. Porém, o sacramento foi realizado, e a comprovação de sua salvação - diferente de conversão - foi justamente sua boa morte.

Em um relato registrado em 1615 , observa-se o caso de um índio que também havia passado pela catequese e necessitou da ajuda batismal para sua salvação:

Outro foi um índio infiel que foi picado a quatro ou cinco léguas de nossa redução. Avisaram-me que já o traziam ao povoado, mas nosso Senhor, que tinha escolhido aquela alma, não me deixava sossegar exaltando meu coração e movendo-me para que eu 
GUILHERME GALHEGOS FELIPPE - O registro do batismo em oposição...

fosse aonde estava aquele índio, ainda que não faltou quem o quisesse estorvar. Contudo, coloquei-me logo a caminho e quando cheguei o índio já estava muito debilitado. Instruí-lhe brevemente. Por já ser catecúmeno não foi muito difícil, mas querendo batizar-se, faltou a água. Fui voando a um pântano buscá-la, batizei-o e logo morreu antes de chegar à redução (MCA-CPH, cx. 28, doc. 11).

Como nos casos anteriores, aqui também é informada a ligação ao catolicismo que o indígena possuía - no caso, a catequese -, o que facilitou, segundo o autor, a aplicação do sacramento. Porém, o autor do relato qualifica-o como um "índio infiel". Parte daí a idéia de que o indivíduo era classificado como pagão, mesmo tendo os ensinamentos iniciais que o capacitariam ao batismo. Sua qualidade de catecúmeno só é lembrada no momento em que o autor do relato aciona o ato batismal, de maneira a informar que aquele indígena tinha mais capacidades para ser batizado. Mas seu ser permanecia ainda como os dos demais: infiel. Isso quer dizer que o batismo urgentista é realizado não em razão de uma qualidade ou vocação do indígena, e sim devido à sua situação física. Sendo ou não catecúmeno, pedindo ou não o batismo, indo atrás do padre ou sendo procurado por este, o sacramento batismal é aplicado urgentemente aos moribundos, ou, em outras palavras, o que move o batismo urgentista não é o indivíduo, e sim sua morte iminente. Pode-se dizer que todos os esforços realizados pelo jesuíta foram direcionados para garantir uma alma, e não uma conversão.

Em relação a isto, salienta-se o fato de que, além de parecer mais importar aos jesuítas a aplicação do sacramento do que a conversão em si, o registro do batismo adquire importância como discurso apologético, por mais infeliz que possa ser o seu desfecho:

Avisaram ao padre que, em uma canoa, estava morrendo uma criança, e, correndo, só teve tempo para jogar-lhe a água do santo batismo e logo espirou. $E$ no caminho achou outro adulto que, recebendo também o santo batismo, foi fazer companhia à ditosa criança que havia ido antes (MCA-CPH, cx. 28, doc. 15). 
GUILHERME GALHEGOS FELIPPE - O registro do batismo em oposição...

Quase que como numa ação mecânica, o jesuíta aplica o batismo aos moribundos, restando-Ihe apenas aguardar suas mortes. Numa realidade como esta, parece ser mais seguro confirmar a realização do ato batismal - e registrá-lo - do que esperar a conversão perpétua de um indígena que passou por todos os ensinamentos catequéticos sem afastar-se do meio reducional:

Todos convienen en que los calchaquíes son tan prontos en recibir la fe católica como en olvidarla sin causa alguna; de cuantos antes fueron bautizados ninguno se conducía como cristiano; justamente con los gentiles, vivían según las antiguas costumbres; por lo cual, acordaron los padres no bautizar a nadie sino in articulo mortis, o cuando estuviera probada su constancia durante varios años (DUVIOLS, 1991, p. 78).

A pesar de retratar os Calchaqui, o trecho escrito pelo padre Nicolás Del Techo ajuda a compreender a difícil relação que os jesuítas tentavam estabelecer entre a religião católica e os indígenas. Como relata o jesuíta, o batismo não assegurava a conversão indígena: muitas vezes, índios batizados voltavam à infidelidade. Apesar disso, administrar o sacramento era função do trabalho jesuítico, bem como relatar aos superiores os ganhos à cristandade e o bom andamento da empresa reducional. Para tal, o padre vê duas saídas: ou o sacramento era aplicado in articulo mortis - como foi demonstrado até aqui -, ou procrastinava-se o batismo, adiando-o até ter-se certeza da vocação do gentio, visto que "muitas vezes não conseguimos obter uma palavra [dos índios] para mostras de que crêem no que lhes dizemos ou que se arrependem de seus pecados" (MCA, 1969, p. 36).

\section{Batismo procrastinado}

Esses relatos envolvendo o adiamento do batismo não são a simples negação por parte dos jesuítas em batizar os gentios, mas sim a prudência em fazê-lo. Assim como o padre Del Techo havia identificado nos índios o desmerecimento ao batismo, pois voltavam quase sempre à infidelidade após a cerimônia, o padre Lorenzana também demonstra 
GUILHERME GALHEGOS FELIPPE - O registro do batismo em oposição...

prudência, escrevendo que só batiza "até que tenham mais conceito" (DHA, 1927, p. 88), e o padre Pedro Romero, quando afirma que "não se Ihes concede [o batismo], senão depois de darem muitas provas e serem ensinados" (MCA, 1970, p. 127).

A procrastinação do batismo se dá quando o padre verifica algum impedimento no indígena que impossibilitaria sua boa conversão, como conta o irmão Fabian Martinez que encontrou "cinco infiéis que vinham de outros povoados [...] e batizei os três, e os [outros dois] deixei, porque tinham impedimentos" (DHA, 1927, p. 68). Com isso, protegese o batismo sacramental: como é a porta de entrada para a cristandade, o sacramento tem uma importância muito grande não só como cerimônia cristã, mas também por ser a confirmação de que o indivíduo foi aceito à religião católica. Daí que o batismo, nestes casos, só era aplicado nos índios depois de muitos ensinamentos e de forma cautelosa, provocando o seu adiamento.

Sempre que percebiam algum motivo que pudesse fazê-los desconfiar das intenções dos indígenas, os jesuítas preferiam atrasar o seu batismo. Esta desconfiança era movida por uma grande variedade de impedimentos que os padres descobriam nos infiéis. Em alguns casos é um pecado grave, como o costume da poligamia:

Muitos pedem o santo batismo com muito fervor, particularmente o capitão, alcaides e outros caciques [...]; mas como eles têm tantos enredos de mulheres, temos que ir devagar com eles (MCA, 1970, p. 70).

Em outros casos, o batismo poderia ser negado a indígenas que não tinham o total conhecimento das orações, demonstrando uma grande exigência por parte dos jesuítas, como é o caso de um casal que teve o seu pedido de batismo negado pelo padre por não saberem o Credo (MCA, 1969, p. 70). Mesmo mostrando grande vontade em serem batizados e demonstrarem conhecimento de outras orações (no caso, o Pai Nosso e a Ave Maria), o casal não teve seu pedido imediatamente realizado, pois, segundo o autor do relato, sua dedicação ainda não era suficiente. Mostrando uma grande exigência, o jesuíta preferiu esperar até que os dois aprendessem mais uma oração, de forma a tê-los mais bem preparados para a conversão. 
GUILHERME GALHEGOS FELIPPE - O registro do batismo em oposição...

Este caso é peculiar se for comparado aos relatos anteriores apresentados até aqui, em que indígenas sem a menor inclinação à religião cristã ou mesmo não querendo ser convertidos recebiam o batismo ou eram submetidos à insistência dos padres para tal. Talvez o que impulsione o jesuíta a adiar o ato batismal no caso supracitado seja justamente a falta de pressa em fazê-lo, já que o casal mostrou interesse na conversão e nenhum do dois estava próximo à morte, colocando o padre numa confortável posição de escolha. Sua opção de procrastinar o batismo foi acertada: ambos trataram de aprender a oração requisitada e o sacramento foi realizado. Porém, nada sobre o destino dos novos cristãos é registrado, não sendo, mais uma vez, um relato sobre conversão.

Mas ainda assim existem relatos em que parece não haver nenhum impedimento concreto que levaria a não-realização do batismo. São casos onde o jesuíta prefere não aplicar o sacramento por não ver razão em fazê-lo, como descreve o padre Romero sobre uma índia que se acidentou e logo chamaram o padre para socorrê-la. A índia "mostrou ter notícias das coisas da fé" e parecia estar bem, o que levou o padre a não "batizá-la por lhe parecer coisa de pouca importância o acidente que sofrera". Porém, sob grande insistência dos seus parentes, sentiu-se inclinado a realizar o sacramento (MCA, 1969, p. 60).

O jesuíta prefere, num primeiro momento, não aplicar o batismo à índia por achar que o acidente não Ihe traria maiores riscos. Desta forma, nega-se em realizá-lo sem apresentar qualquer impedimento pelo contrário, escreve que a índia tinha conhecimentos acerca da religião cristã, o que favoreceria a sua conversão. Mas a importância do relato está no fato de os parentes da índia terem insistido para que o padre aplicasse o batismo. Provavelmente o padre Romero tinha a intenção de registrar o bom andamento da empresa evangélica, mostrando um caso onde os próprios indígenas pediam o sacramento. Contudo, este fato não encobre a primeira atitude do inaciano, que opta por adiar um batismo a uma índia que demonstrava vocação. Aparentemente, o autor tentou focar em seu discurso o fato de os índios terem suplicado a realização do sacramento - até porque, mais adiante na carta, Romero afirma que muitos índios reivindicavam o batismo, fazendo "extremos quando os padres não queriam ou dilatavam sua 
GUILHERME GALHEGOS FELIPPE - O registro do batismo em oposição...

realização" (MCA, 1969, p. 70) -, mas, em detrimento, disto negligência o trabalho apostólico.

O mesmo ocorre a outro índio, também doente, "de idade decrépita", que solicitou o sacramento, mas teve seu pedido adiado, "porque não mostrava ter risco" (MCA, 1951, p. 207). O caso termina com o batismo do índio sendo administrado por um padre que, sentindo-se "interiormente movido", decidiu, enfim, sacramentá-lo. Porém, mais uma vez, o jesuíta opta, num primeiro momento, por não batizar o indígena, alegando que não corria risco de morte. A procrastinação do batismo, nestes casos, parece ser uma forma de os padres protegerem o sacramento: não administrá-lo sem maiores necessidades, tendo a prudência em fazê-lo apenas em casos realmente necessários. Acostumados a presenciar situações em que índios recémbatizados voltam à infidelidade, os jesuítas optam pelo adiamento - ou mesmo negação - do batismo, ainda que não exista impedimento concreto que justifiquem tal escolha.

Assim, o adiamento do batismo poderia ser feito por causa de um impedimento existente no indígena ou movido pela escolha arbitrária do jesuíta por não achar necessário realizar o sacramento. De qualquer forma, o que se sabe é que esta atitude, independente de sua justificativa, é uma resposta jesuítica ao comportamento inadequado indígena, ou seja, vendo a dificuldade em fazê-los permanecerem batizados, os padres passam a ter prudência para com os candidatos ao sacramento. Como se viu, batizar não significa converter, pois os neófitos sempre podem voltar à infidelidade. Para se ter mais claro o assunto, observa-se dois casos distintos:

Outro índio, cacique, estava muito doente e tinha consigo uma manceba. Vendo-o bastante debilitado, o padre queria batizá-lo e assim the disse que se não deixasse a má companhia que tinha, não podia ser filho de Deus. O primeiro dia em que o padre o viu, não respondeu nada. O segundo dia em que Ihe foi ver o padre outra vez e tratar da mesma matéria, tocado já de nosso Senhor, o cacique disse que em hora muito boa e com muito gosto queria deixar a manceba e tirála de sua casa, porque amava mais sua alma do que ela. Estando já muito debilitado, pediu com muita vontade ao padre que 0 batizasse. Aplicou-lhe 0 
GUILHERME GALHEGOS FELIPPE - O registro do batismo em oposição...

batismo e logo morreu com prendas de sua eterna salvação (MCA, 1970, p. 124).

Mesmo percebendo que o cacique necessitava do batismo e tendo a oportunidade de realizá-lo, o padre não o fez, pois via um grande impedimento: seu amancebamento. Mais do que procrastinar, o jesuíta estava negando-se a converter o índio se ele permanecesse naquelas condições errôneas. Mesmo apresentando um infiel gravemente doente com risco de morte, o registro teve outra conotação diferente dos batismos urgentes, pois existia um pecado nefando que se sobrepunha à necessidade de batizar 0 indígena. A urgência em aplicar 0 sacramento a índios próximos à morte esbarrou em um impedimento concreto e intransponível. O cacique só adquiriu sua salvação porque desistiu de sua manceba. Esta atitude veio a dar razão à escolha do jesuíta: sua prudência foi bem justificada com o fim da união pagã e o arrependimento do índio, porém resultando em um relato batismal, e não em caso de conversão eficaz. Em contraponto, observa-se o segundo caso:

\begin{abstract}
Uma pobre e infeliz índia, a qual a princípio mostrou ter desejos de ser cristã e assim entrava com cuidado na igreja para rezar e tudo mais, pedia também ao padre que a batizasse. Contudo ele adiava-o para que ela aprendesse mais e, principalmente, porque seu marido era um feiticeiro há muitos anos e seria precipitado dar-Ihe o batismo por alguns dias, porque alguns querem logo batizar-se e depois voltam a seus embustes e feitiçarias com menosprezo de tão grande sacramento. Por isto, com eles, é necessário ir com muita cautela, até ver se o pedem de verdade. A índia, como viu que o padre dava-Ihes tantas delongas e esperas, cansou-se e não voltou mais à igreja. Foi à sua terra onde, em castigo de ter voltado as costas a Deus, acometeu-a uma grave doença. Vendo-a doente, os de sua casa foram avisar o padre, que, mesmo apressando-se, quando chegou já estava morta (MCA, 1969, p. 64-65).
\end{abstract}

Mesmo sendo uma freqüentadora assídua da igreja e apta à conversão, o padre queria que ela fosse mais bem preparada para o batismo e que largasse o seu companheiro. Por levar uma vida contraditória - já que inclinada à fé cristã, mas casada com um xamã -, 
GUILHERME GALHEGOS FELIPPE - O registro do batismo em oposição...

o jesuíta decide adiar seu batismo até que ela largasse o feiticeiro e mostrasse mais conhecimento à nova religião. Porém, cansada de esperar, a índia não só deixa de freqüentar a igreja, como volta à sua antiga terra, demonstrando, segundo o autor, uma inaptidão à cristandade. É castigada por Deus e só então o padre, com urgência, procura aplicar-lhe o batismo, não alcançando o seu intento. Sem a realização do sacramento, a índia tem uma morte ruim dando razão ao jesuíta que optou por não realizar seu batismo. Tal escolha do padre, como no caso anterior, é justificada pelo desfecho do relato, com a diferença que, naquele, o índio deixou de ser um pecador; neste, a índia tornou-se uma. Ambos os casos comprovaram que o indígena sempre pode voltar atrás, tanto para o mal como para o bem, dificultando as decisões que os jesuítas deveriam tomar.

\section{Considerações finais}

Aplicar o batismo sacramental a estes nativos viria a ser a primeira grande vitória da empresa reducional. Porém, como se observou nos relatos, foi apenas uma vitória parcial. A não-aceitação dos índios à conversão ficou evidente nos registros documentais quando se analisou as atitudes indígenas perante a iniciativa dos padres em batizá-los. 0 desbatismo ou o medo do batismo evidenciam uma mesma intenção destes índios que era contrária àquela esperada pelos jesuítas, bem como as ações que os padres passaram a realizar com os batismos urgentistas e a procrastinação do batismo.

O discurso jesuítico pautou-se em afirmar a importância do ato sacramental em razão da falta de atitudes indígenas que respondessem positivamente à boa inserção do batismo em sua vida reducional. Não existindo uma expressiva conduta satisfatória dos novos cristãos, os padres passaram a sustentar seus discursos nos casos modelares edificantes, que tinham como objetivo afirmar, de forma enaltecedora, a realização do batismo aos índios. Porém, o comportamento indígena forçou, muitas vezes, os jesuítas a desviarem-se deste modelo, gerando variações discursivas. Com isto, evidencia-se o comportamento indígena indesejado pelos padres, onde os nativos aderem ao meio 
GUILHERME GALHEGOS FELIPPE - O registro do batismo em oposição...

reducional, sem deixarem, no entanto, de viver de acordo com sua cultura, tradição e costumes. Baseados em "su capacidad para incorporar y resignificar elementos previos en el nuevo escenario de contacto" (WILDE, 2003, p. 204), adaptaram o sacramento à sua vida conforme as possibilidades e necessidades, mas sem estabelecer uma relação profunda com as condutas e dogmas cristãos.

A convivência entre os índios reduzidos e os jesuítas estabeleceuse em uma relação mútua, porém dificultosa para ambos os lados. Os padres, guiados pelas suas crenças e visão de mundo, observavam, interpretavam e registravam as condutas nativas de maneira depreciativa. Com isso, justificavam seu intento em implantar normas e práticas cristãs, fundamentadas no batismo. Por sua vez, as atitudes indígenas não corresponderam àquelas esperadas pelos padres, que tiveram que adequar sua forma de cristianizar, pelo menos no que tange à questão dos registros. Deve-se a isso a grande incidência de casos que se contentam em registrar a aplicação do batismo, e não em enaltecer a conversão. Do outro lado, os índios reduzidos aceitaram estabelecer uma aliança com os jesuítas, confiando e respeitando-os, mas sem abrir mão de sua liberdade. É inegável que tenham vivido nas reduções, participado de celebrações, assistido às missas, aprendido orações e que tenham sido batizados, porém não viviam exclusivamente para estas situações. Longe de serem simples fantoches a disposição dos padres (WILDE, 2001, p. 10), conseguiram manter seus costumes e tradições, ao mesmo tempo em que viviam no meio reducional e, sempre que queriam ou achavam necessário, retiravam-se para as suas antigas terras.

\section{Referências Bibliográficas}

CHAMORRO, Graciela. Teología Guaraní. Quito: Abya-Yala, 2004.

DELUMEAU, Jean. História do medo no Ocidente: 1300-1800, uma cidade sitiada. São Paulo: Companhia das Letras, 1989. 
GUILHERME GALHEGOS FELIPPE - O registro do batismo em oposição...

FLECK, Eliane Cristina Deckmann. Da mística às luzes: a medicina experimental nas reduções jesuítico-guaranis da Província Jesuítica do Paraguai. Revista Complutense de Historia de América, Madrid, v. 32, p. 153-178, 2006.

LABORIE, Jean-Claude. A Dispersão do Saber Missionário sobre as Américas de 1549 a 1610: o exemplo jesuíta. Revista de História, São Paulo, n. 152, p. 9-27, 2005.

LONDOÑO, Fernando Torres. Escrevendo cartas. Jesuítas, escrita e missão no século XVI. Revista Brasileira de História, São Paulo, v. 22, n. 43, p. 11-32, 2002.

MELIÀ, Bartomeu. El Guaraní Conquistado y Reducido: Ensayos de etnohistoria. Asunción: Biblioteca Paraguaya de Antropología, 1988.

El guaraní: experiencia religiosa. Asunción: CEDUC-CEPAG, 1991a.

. Misión por reducción. Suplemento Antropológico, Asunción, v. XXVI, n. 1, p. 213-228, $1991 b$.

PALOMO, Federico. Corregir letras para unir espíritus: los jesuitas y las cartas edificantes en el Portugal del siglo XVI. Cuadernos de Historia Moderna, Anejos, n. 4, p. 57-81, 2005.

POMPA, Cristina. Profetas e santidades selvagens: missionários e caraíbas no Brasil colonial. Revista Brasileira de História, São Paulo, v. 21, n. 40, p. 177-193, 2001.

RÍPODAS ARDANAZ, Daisy. Pervivencia de hechiceros en las misiones Guaraníes. Folia Histórica del Nordeste, Resistencia, n. 6, p. 199-217, 1984.

Movimientos Shamanicos de Liberación entre los Guaraníes (1545-1660). Teología, Buenos Aires, tomo XXIV, n. 50, p. 245-275, 1987.

SANTOS, Maria Cristina dos. Fronteiras Internas do Rio da Prata Colonial: Rebeldes e Desertores. In: Anais das VI Jornadas Internacionais Sobre as Missões Jesuíticas : As Missões Jesuíticas del Guairá. Cascavel: Edunioeste, p. 319-349, 1998.

WILDE, Guillermo. De la Coacción a las Estrategias: algunas reconsideraciones sobre el modo de producción jesuítico guaraní. Razón y Revolución, n. 7., 2001. Disponível em: <http://www.razonyrevolucion.org/textos/revryr/luchadeclases/ryr7Wilde. pdf $>$. Acesso em: 10 ago. 2007.

Poderes del ritual y rituales del poder: un análisis de las celebraciones en los pueblos jesuíticos de guaraníes. Revista Española de Antropología Americana, Madrid, n. 33, p. 203-229, 2003. 
GUILHERME GALHEGOS FELIPPE - O registro do batismo em oposição...

\section{Referências documentais}

Fontes manuscritas

Manuscritos da Coleção de Angelis (MCA-CPH) ${ }^{8}$

Cx. 25, doc. 14 1614. Breve noticia de la misión de los Guaycurús. (n 781).

Cx. 28, doc. 11 1615. Carta annua de las misiones del Paraná. (n 859).

Cx. 28, doc. 12 1616. Relación de la misión de San Ignacio del Paraná. ( $\left.\mathrm{n}^{\circ} \quad 860\right)$.

Cx. 28, doc. 15 1619. Carta annua de la reducción de N. ${ }^{\text {tra }}$ S. ${ }^{\text {ra }}$ de la Encarnación de Itapuã. (n 863$)$.

Cx. 28, doc. 17 1621. Estado general de la reducción de Encarnación de Itapuã. $\left(n^{\circ} 865\right)$.

Cx. 28, doc. 18 1624. Annua de la nueva reducción de $N^{\text {tra }}$ S. $^{r a}$ de la Natividad del Acaray. $\left(\mathrm{n}^{\circ} 866\right)$.

Cx. 28, doc. 22 1627. Estado de la reducción de N. ${ }^{\text {tra }}$ S. $^{\text {ra }}$ de los Reyes. $\left(\mathrm{n}^{\circ} \quad\right.$ 870).

Fontes impressas

DOCUMENTOS PARA LA HISTORIA ARGENTINA (DHA). Cartas anuas de la Provincia del Paraguay, Chile y Tucumán, de la Compañía de Jesús (1609-1614). Tomo XIX, Buenos Aires: Talleres S. A. Casa Jacobo Peuser, 1927.

Cartas anuas de la Provincia del Paraguay, Chile y Tucumán, de la Compañía de Jesús (1615-1637). Tomo XX, Buenos Aires: Talleres S. A. Casa Jacobo Peuser. 1929.

DUVIOLS, Jean-Paul e SAGUIER, Rubén Bareiro (Org.). Tentación de la Utopía. Barcelona: Tusquets, 1991.

MANUSCRITOS DA COLEÇÃO DE ANGELIS (MCA). Jesuítas e Bandeirantes no Guairá (1549-1640). v. I, Rio de Janeiro: Biblioteca Nacional, 1951. (introdução, notas e glossário por Jaime Cortesão).

Jesuítas e Bandeirantes no Itatim (1596-1760). v. II, Rio de Janeiro: Biblioteca Nacional, 1952. (introdução, notas e glossário por Jaime Cortesão).

\footnotetext{
${ }^{8}$ As referências dos documentos manuscritos estão de acordo com a localização dos microfilmes no Centro de Pesquisas Históricas do Programa de Pós-Graduação em História da PUCRS. Tais cópias microfilmadas foram adquiridas através de um projeto financiado pelo $\mathrm{CNPq}$, cujos originais pertencem à Biblioteca Nacional do RJ.
} 
GUILHERME GALHEGOS FELIPPE - O registro do batismo em oposição...

. Jesuítas e Bandeirantes no Tape (1615-1641). v. III, Rio de Janeiro: Biblioteca Nacional, 1969. (introdução, notas e glossário por Jaime Cortesão).

Jesuítas e Bandeirantes no Uruguai (1611-1758). v. IV, Rio de Janeiro: Biblioteca Nacional, 1970. (introdução, notas e sumário por Hélio Vianna).

RUIZ DE MONTOYA, Pe. Antonio. Conquista Espiritual Feita pelos Religiosos da Companhia de Jesus nas Províncias do Paraguai, Paraná, Uruguai e Tape [1639]. Porto Alegre: Martins Livreiro, 1985. 